\title{
Research Paper \\ The Effect of Cognitive Emotion Regulation Training on the Signs of Anger in Boys with Attention Deficit/ Hyperactivity Disorder (ADHD)
}

\section{Marjan Kashani $^{1}$, Parviz Asgari*2 ${ }^{* 2}$ Fariborz Dortaj ${ }^{3 \& 4}$, Parvin Ehteshamzadeh $^{2}$ Zahra Eftekhar $^{5}$}

1. Ph.D. Student of General Psychology, Ahvaz Branch, Islamic Azad University, Ahvaz, Iran

2. Associate Professor, Department of Psychology, Ahvaz Branch, Islamic Azad University, Ahvaz, Iran

3. Professor, Department of Psychology, Ahvaz Branch, Islamic Azad University, Ahvaz, Iran

4. Professor, Department of Psychology, Faculty of Psychology and Educational Sciences, Allamah Tabatabaei University, Tehran, Iran

5. Assistant Professor, Department of Psychology, Ahvaz Branch, Islamic Azad University, Ahvaz, Iran

Citation: Kashani M, Asgari P, Dortaj F, Ehteshamzadeh P, Eftekhar Z. The effect of cognitive emotion regulation training on the signs of anger in boys with attention deficit/ hyperactivity disorder (adhd). Quarterly Journal of Child Mental Health. 2020; 7(3): 314-325.

\section{http://dx.doi.org/10.52547/jcmh.7.3.25}

\section{A R T I C L E I N F O}

\section{Keywords:}

Cognitive emotion regulation, anger, Attention Deficit/ Hyperactivity Disorder (ADHD)

Received: 2 Jun 2018 Accepted: 13 Oct 2018 Available: 7 Dec 2020

\section{A B S T R A C T}

Background and Purpose: Considering the results of different studies indicating emotion regulation difficulties in children with Attention Deficit/ Hyperactivity Disorder (ADHD), efforts are made here to determine the effect of cognitive emotion regulation training on the anger of boys with ADHD.

Method: This study was a quasi-experimental study with pretest-posttest control group design. The sample consisted of forty 12-year-old primary school boys with ADHD in Tehran in the academic year 2016-2017, selected by multi-stage cluster sampling and then randomly placed into the control and experimental groups. After running the pretest on both groups, the experimental group underwent twelve 45-min sessions of cognitive emotion regulation training while the control group received no intervention. Questionnaire of Children's Behavioral Problems- Parent Form (Conners, 1970) and State-Trait Anger Expression Inventory (Spielberger, 1999) were used to gather the data. ANCOVA was used to analyze the data.

Results: The results of data analysis showed that cognitive emotion regulation training significantly decreased the anger in boys with $\operatorname{ADHD}(\mathrm{F}=27.83, \mathrm{p}>0.05)$.

Conclusion: Students with ADHD are not so much capable to control their negative emotions. Cognitive emotion regulation training can reinforce the positive emotions in these children and led to the reduction of anger in them.

\footnotetext{
* Corresponding author: Parviz Asgari, Associate Professor, Department of Psychology, Ahvaz Branch, Islamic Azad University, Ahvaz, Iran. E-mail addresses: P.Asgary@iauahvaz.ac.ir
} 


\title{
تأثير آموزش تنظيم شناختى هيجان بر نشانههاى خشم كودكان يسر با اختلال نارسايى توجه/ فزون كنشى
}

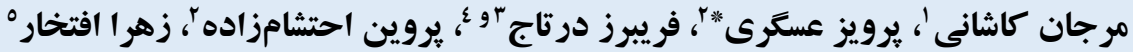

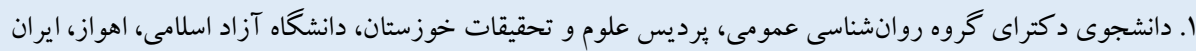

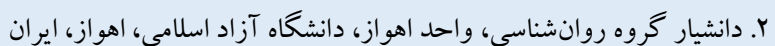

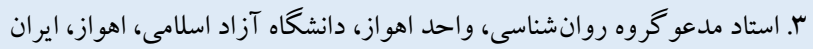 \\ ץ. استاد گروه روانشناسى، داتشكده روانشناسى و علوم تربيتى، دانشگاه علامه طباطبايى، تهران، ايران

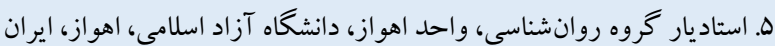

\section{جكيuه}

زمينه و هدف: با توجه به نتايج مطالعات مختلف حاكى از مشكلات خودتنظيمى هيجانى در كود كان با اختلال نارسايى توجه/ فزون كنشى، ئزوهش حاضر با هدف تعيين اثربخشى آموزش تنظيم شناختى هيجان بر نمره خشم كود كان يسر مبتلا به اين اختلال انجام شد.

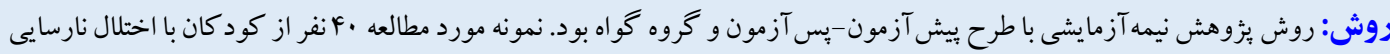

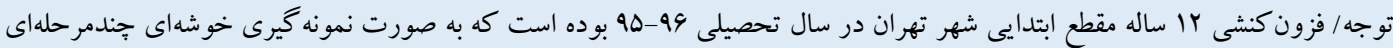

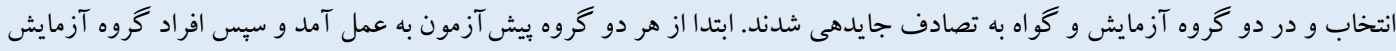

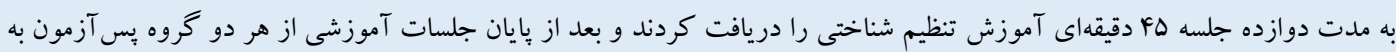

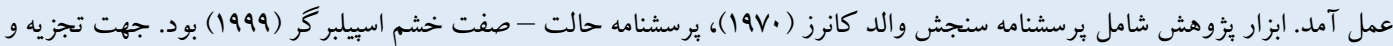

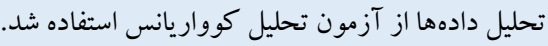
يافتها: نتايج تحليل كوواريانس نشان داده است كه آموزش تنظيم شناختى هيجان به طور معنادار موجب كاهش خشم كود كان يسر با

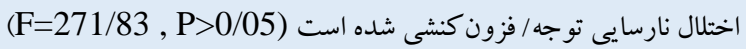
نتيجه گيرى: دانش آموزان با اختلال نارسايى توجه / فزون كنشى در مهار هيجانات منفى، مهارت جندانى ندارند. با آموزش تنظيم شناختى هيجان مى توان جايگزينى هيجانات مثبت را تقويت كرد و اين موضوع به كاهش خشم كود كان با اختلال نارسايى توجه/ فزون كنشى منجر مىشود.
مشخصات مقاله

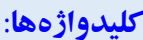

تنظيم شناختى هيجان، خشم، نارسايى توجه/ فزون كنشى

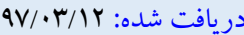

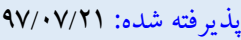
منتشر شده: 99/.9/

* نويسنده مسئول: يرويز عسخرى، دانشيار گروه روانشناسى، واحد اهواز، دانشكاه آزاد اسلامى، اهواز، ايران.

P.Asgary@iauahvaz.ac.ir رايانامهن 


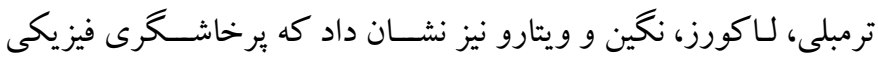

مقدمه

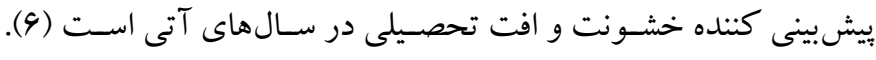

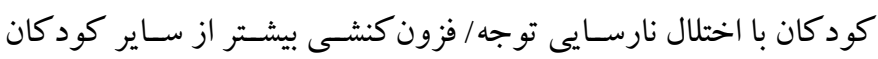

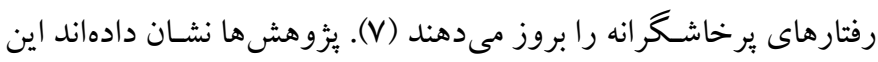

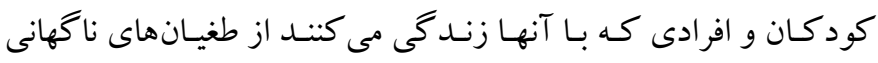

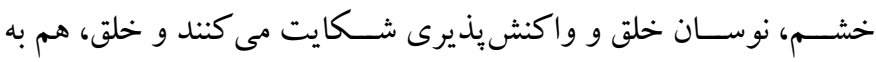

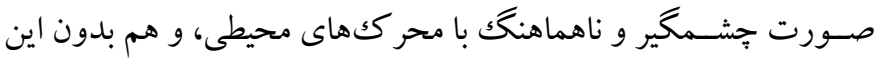

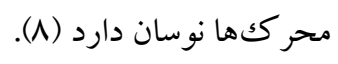

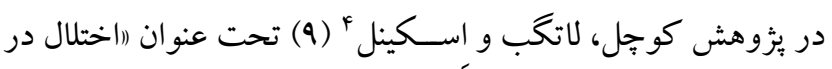

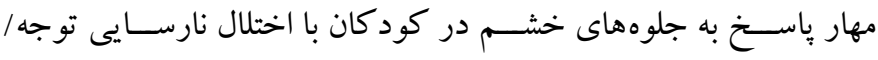

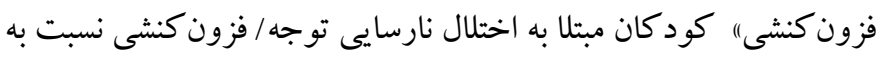

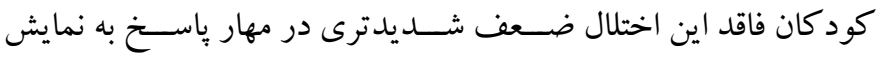
جلوههاى خشــم داشــتند. در بسـيارى از موارد اختلال نارسـايى توجه/

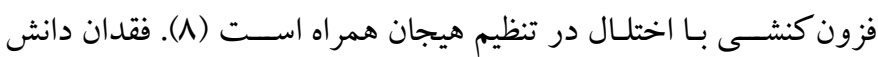

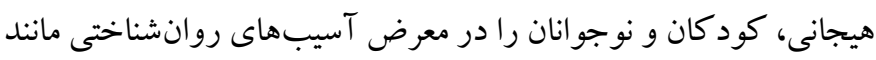

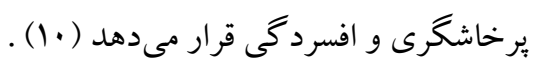

جهت بهبود مؤلفههاى روانشناختى، اجتماعى، و هيجانى كود كان و

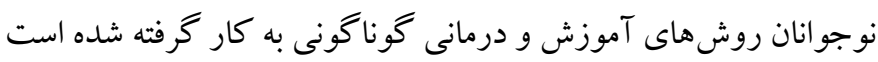

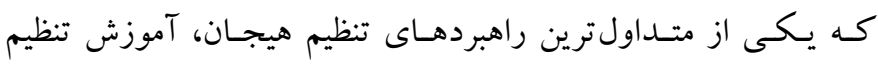
شـناختى - هيجانى گراس اسـت. تنظيم هيجان، كنشى است كه به وسيله

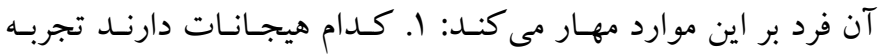

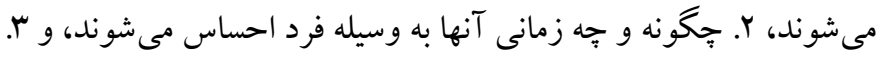

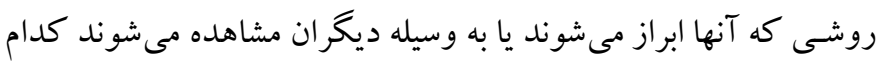

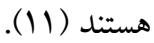

كراسه ه 1991 ينج مجموعـه از فراينـدهـا (انتخـاب موقعيـت، تغيير موقعيت، گَسـترش توجه، تغيير شــناختى، و تعديل باســخ) كه در تنظيم

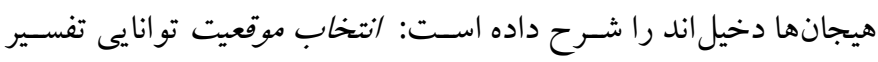

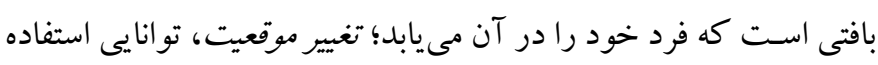

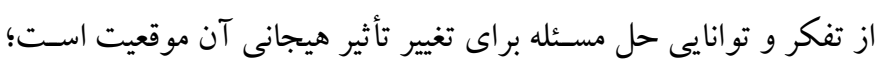

4. Köchel, Leutgeb, \& Schienle

5. Gross
اختلال نارسـايى توجه/ فزون كنشـى' بر اسـاس وير ايش ينجم راهنماى

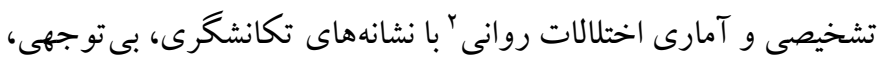

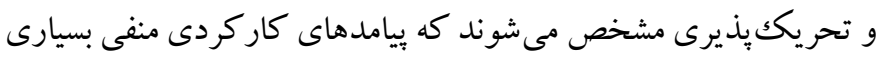
مانند كاهش عملكرد تحصـيلى، عدم ييشـرفت تحصسيلى و تعارضـات ميـانفردى بـالـا را براى كودكـان بـا اين اختلـال بـهـ همراه دارد (1).

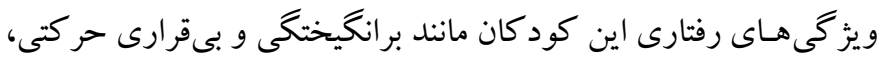

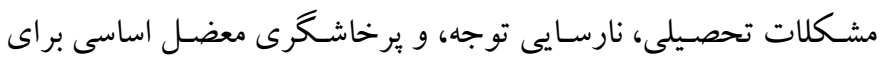

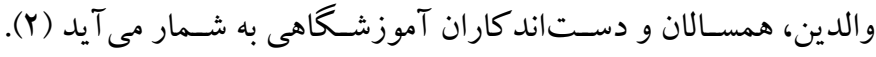

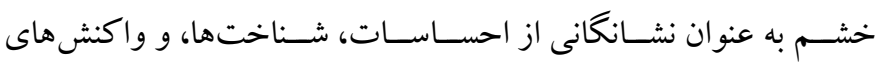

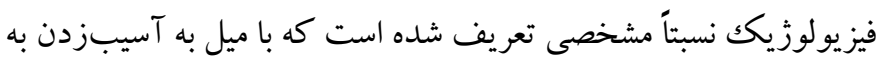

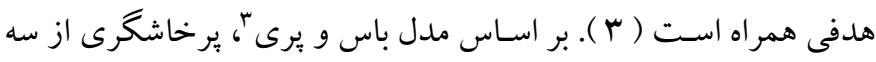

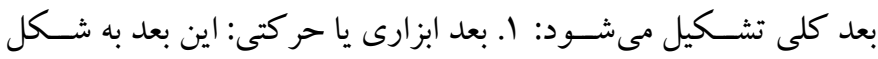

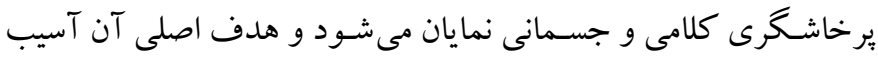

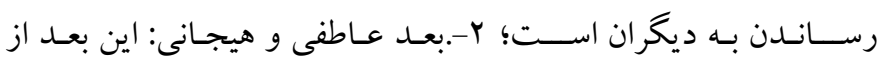

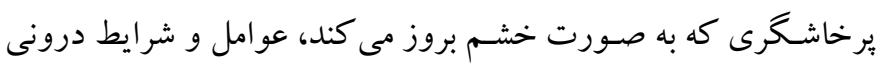

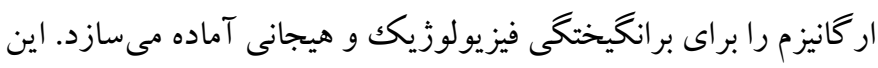

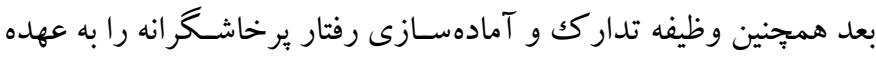
دارد؛ و م. بعد شــناختى: اين عامل كه خصــومت نام دارد ســبب ايجاد احسـاس غرضورزى، دشـمنى، و كينه توزى نسـبت به ديخران مىشـود.

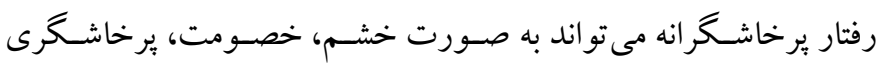

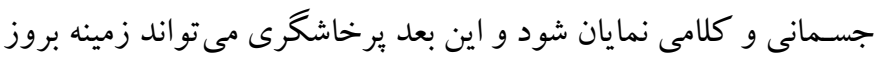
انواع آسيب هاى جسمانى و روانشناختى را فراهم آورد (F).

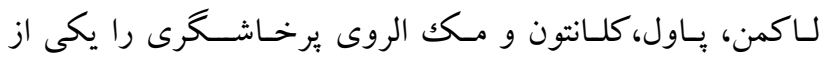

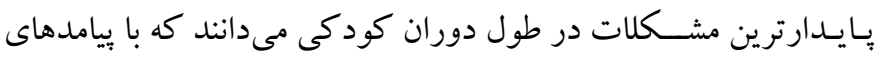

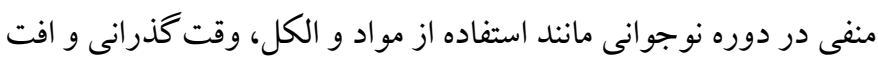

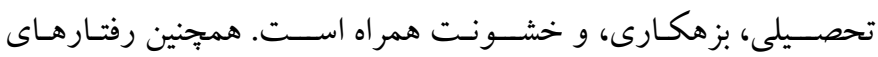

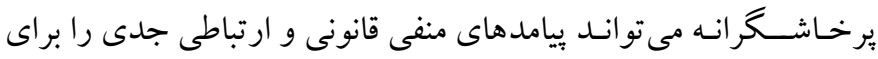

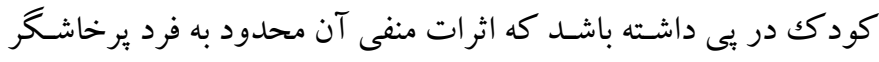

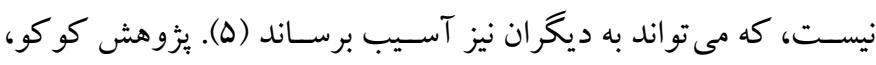

1. Attention Deficit Hyperactivity Disorder (ADHD)

2. Diagnostic and stastistical manual of mental disorder 3. Buss, Peery 
حياتى هستند. تنظيم هيجان براى عملكرد مثبت ضرورى است و مىتواند

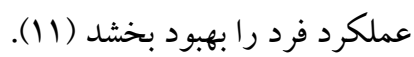

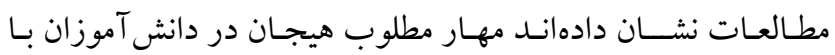

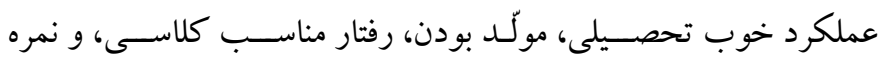

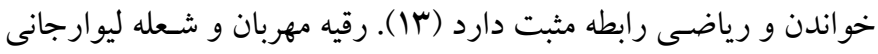

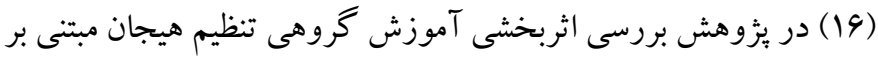

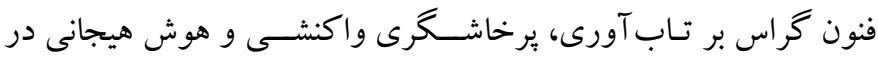

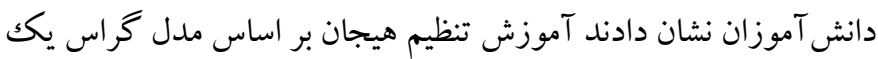

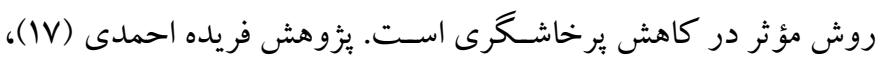

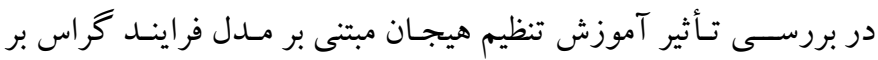

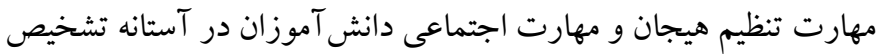
اختلال نارسـايى توجه/ فزون كنشى نشـان داد كه آموزش مهارت تنظيم

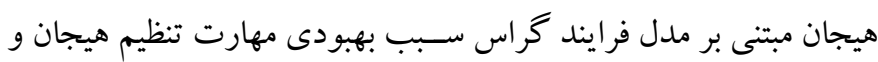

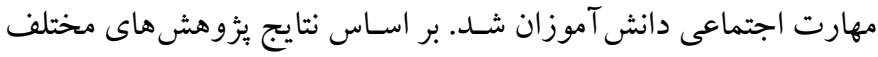

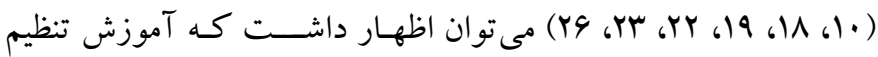
شـناختى هيجان در بهبود مؤ لفه هاى روانشــناختى مانند خشــم، كاهش

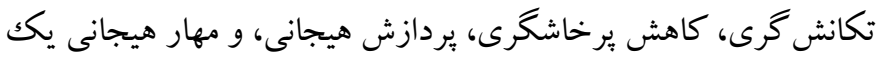

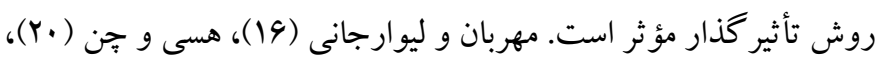

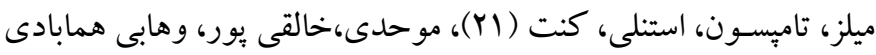
(YF)

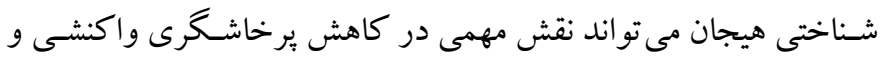

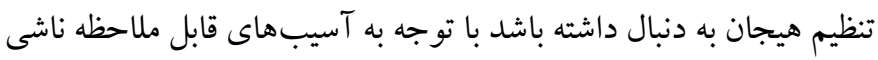

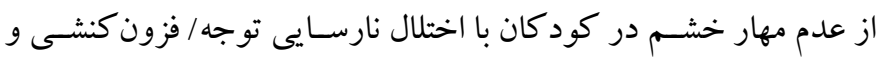
فقدان مطالعات كافى و ضـرورت شــاسـايى راهبردها و مداخله مؤثر در اين حوزه، يُوهش حاضر با هدف بررسى تأثير آموزش تنظيم شناختى

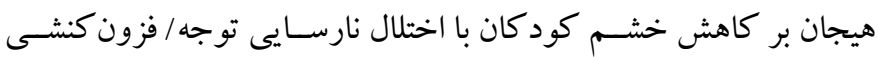

6. Positive reappraisal

7. Putting in to perspective

8. Refocus on planning

9. Acceptance
كسـترش توجه، تغيير تمر كز از موقعيتى مىباشــــــه فعال كننده هيجان

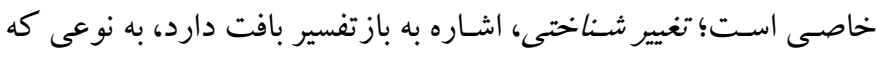

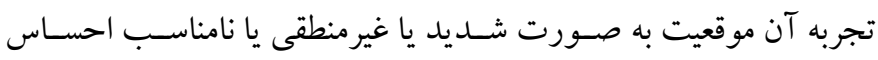
نمى شود؛؛ و تعديل پاسخخ، به راهبردهايى اشاره دارد كه براى جدا كردن

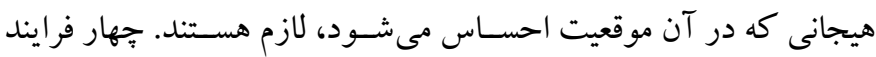

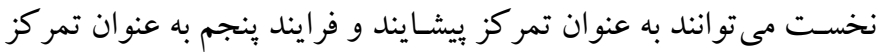

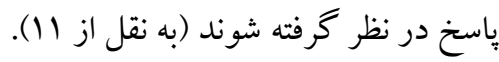

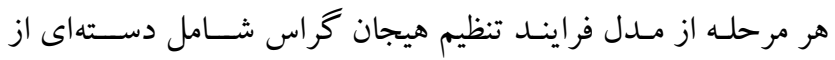

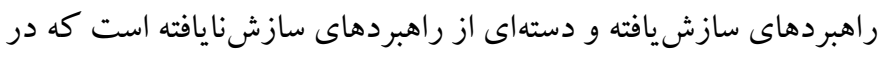

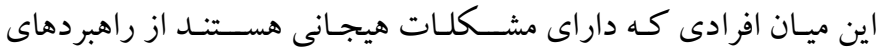

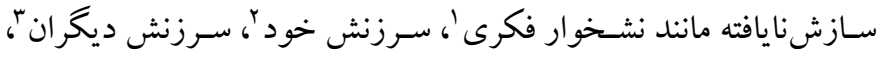

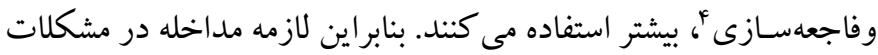

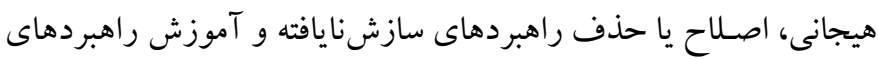

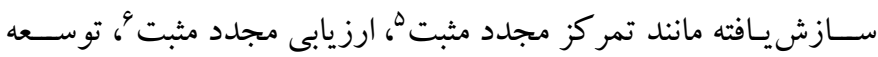

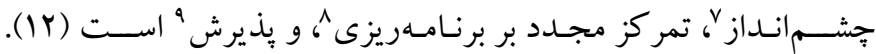

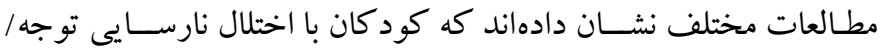
فزون كنشى بيشتر از راهبردهاى سازشنايافته مهار هيجان استفاده مى كنند

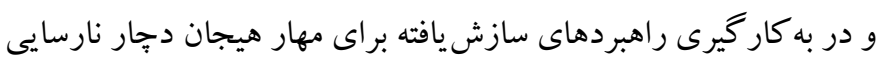

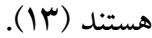
مطالعات نشـان مى دهند، راهبردهاى تنظيم شــناختى هيجان به افر اد كمك مى كنند تا برانگيختخى ها و هيجانهاى منفى را تنظيم كنند (If).

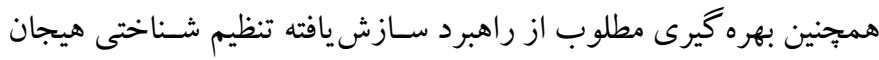
مانند ارزيابى مجدد، باعث كاهش احساسات منفى، و افزايش احساسات

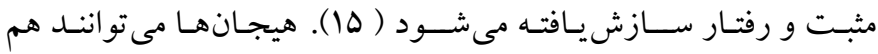
ســازمـاندهنده توجه و هم مانعى براى ســـازماندهى توجه باشــند؛ هم

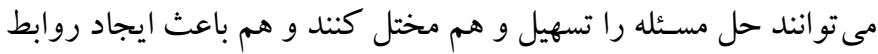
و هم تخريب آن شوند. اين تعاملات دوسويه ضرورت موت كمك به به كود كان

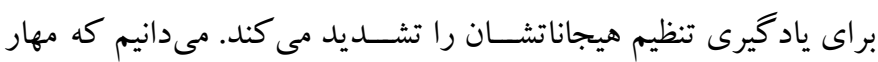
توجه، حل مشكل و روابط سالم، براى موفقيت تحصيلى و رضايت فردى

1. Rumination

2. self-blame

3. Other-blame

4. Catastrophic

5. Positive refocusing 
فزون كنشى و تكانشخرى، اضطراب، و مشكلات ياد گيرى را اندازه گيرى

مى كند. سؤوالات بر اساس مقياس جهار گزينهاى ليكرت ( • = هر گزم، 1 =

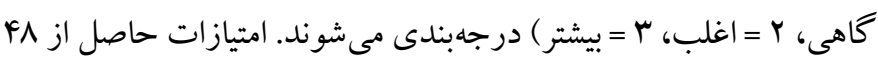

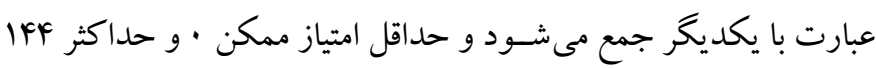

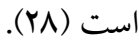
روايى و يايايى اين مقياس در مطالعات متنوع در كشـورهاى مختلف

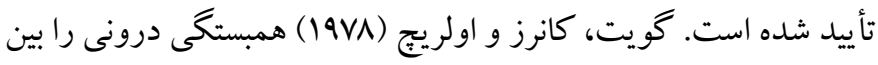

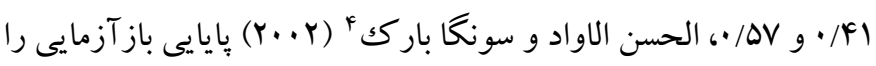

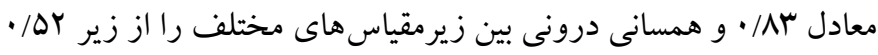
( زيرمقياس اضطراب) تا • ^/· • نارسايى توجه/ فزون كنشى)، و كانرز و

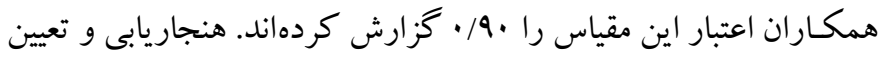
روايى و بايايى مقياس درجهبندى برسشنامه كانرز فرم كو تاه ويزه والدين

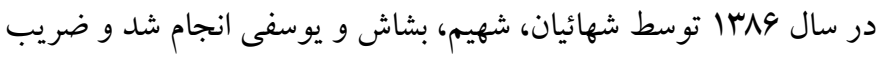

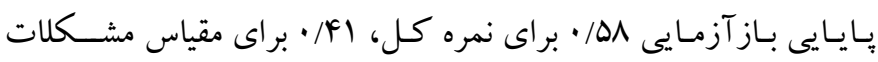

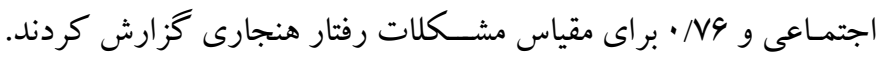

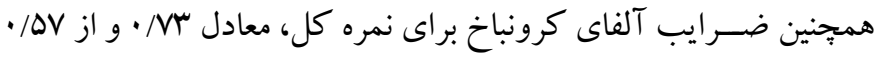
(زيرمقياس مشكلات اجتماعى) تا \^/· (زيرمقياس اضطراب - خجالتى)

$$
\text { براى زيرمقياس ها گزارش شد (Y^). }
$$

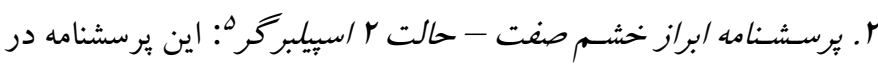

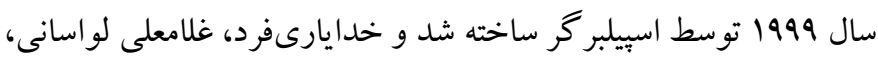

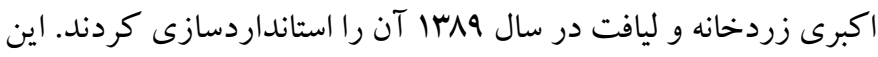

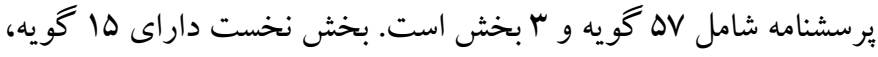

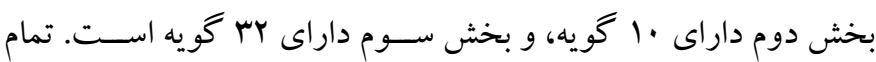

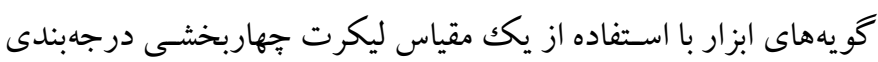

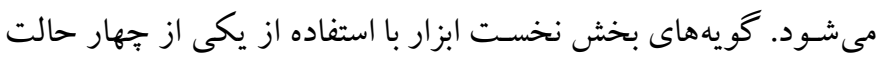

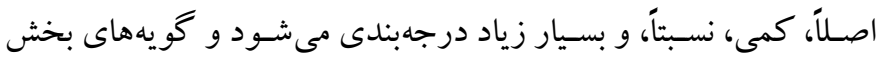

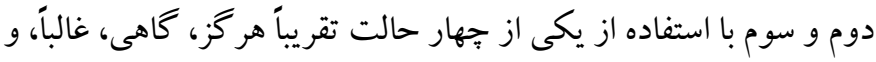

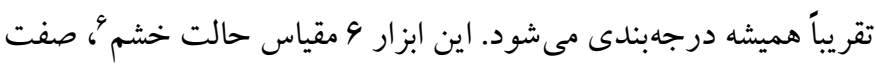

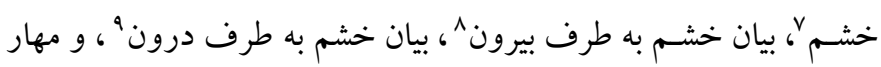

\section{State anger}

7. Trait anger

8. Anger expression-out

9. Anger expression-in

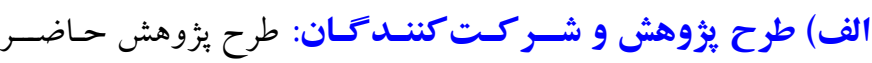

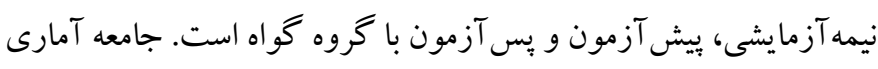

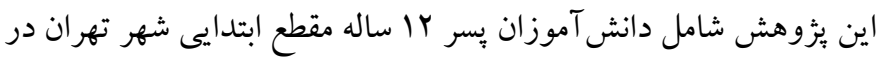

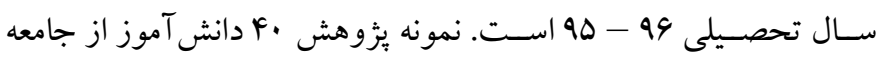

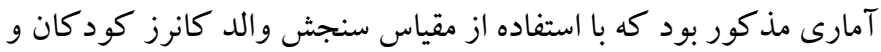

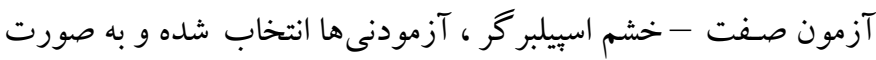

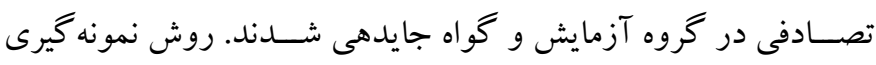

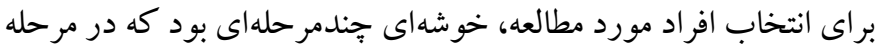
نخسـت از منـاطق شـهر تهر ان ثأمنطقه و در مرحله دوم از هر منطقه مدرسـه به صسورت تصادفى انتخاب شدند. بر اساس بيشنهاد متخصصان،

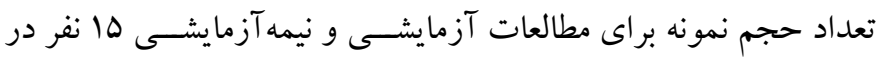

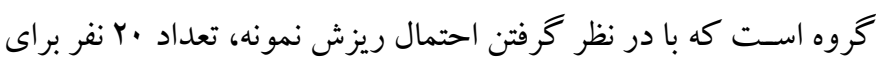

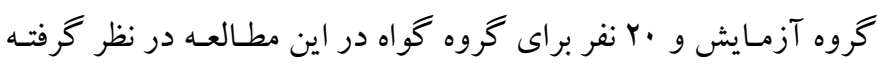

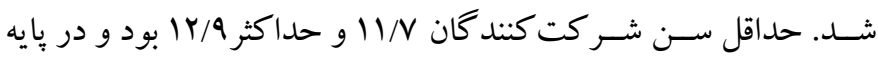

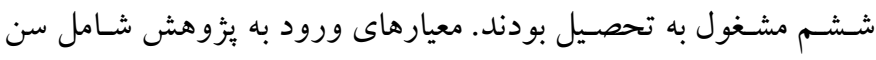

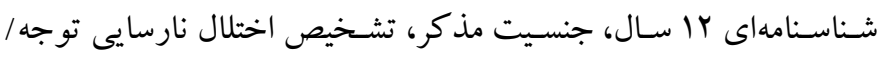

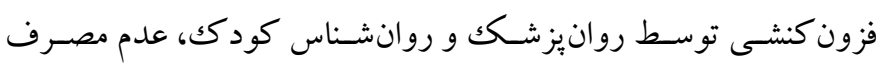
دارو، و عـدم ابتلـا بـه اختلال جســمانى و روانى (مانند ناشــنو ايى، انواع نقص هاى حسى و حر كتى، بيمارى ديابت، سـاير اختلالات روانى مانند

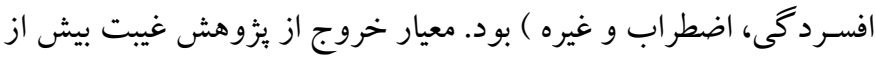

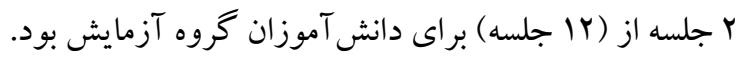

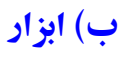
ا. مقياس مشـكلات رفتارى كودكسان كـانرز فرم والـدين ': مقيساس

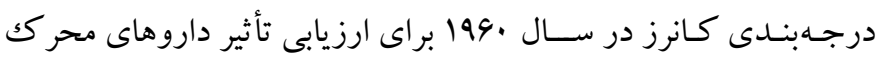

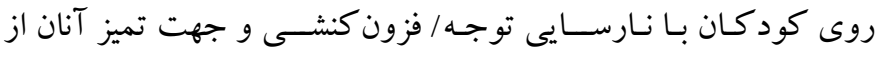

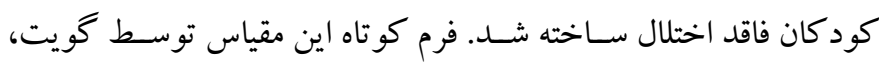

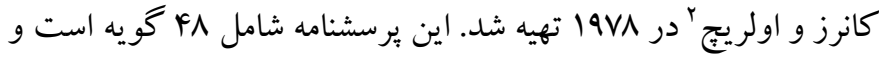

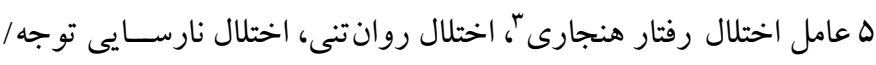

1. Conner's parents rating of chilhood behavior problems 1969

2. Goyett, Conners, Ulrich

3. Conduct disorder

4. El-hassan Al-awad \&Sonuga Barek

5. Inventory Spielberger's state-trait anger expression inventory-2 
هيجان است، استفاده شد. اين بروتكل توسط جيمز گراس ساخته شده و

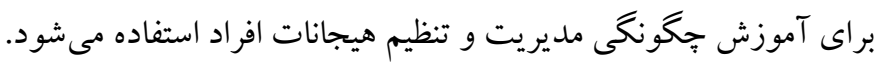

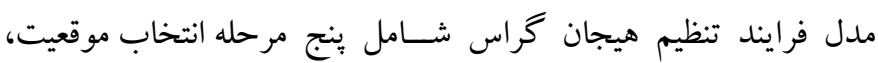

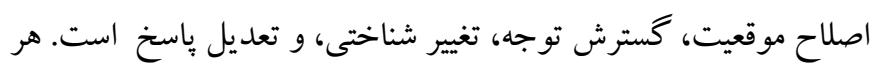
مرحله شـامل دامنهاى از راهبردهاى سـازشيافته و سـازشنايافته است. افراد دجار مشـكلات هيجانى، بيشـتر از راهبردهاى سـازشنايافته مانند

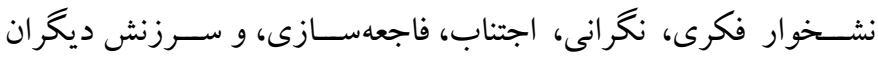

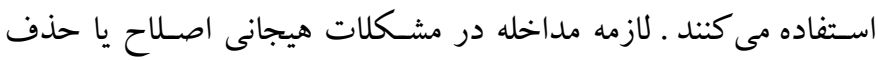
راهبردهاى سازشنايافته و آموزش راهبردهاى سازش يافته است. (19)

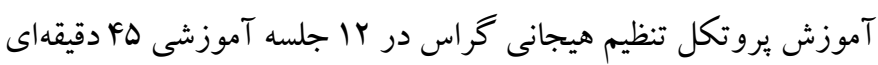

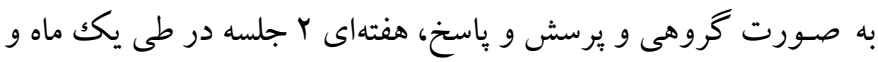

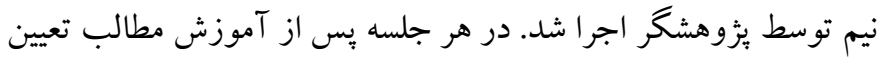

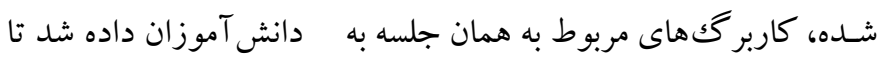

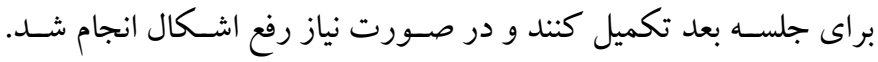
برنامه و محتواى جلسـات آموزش تنظيم شــاختى هيجان به تفصسيل در جدول ا ززارش شـــه اسـت. اولين جلســه با والدين جهت معارفه و همجينين بيان هدف آموزش تنظيم شـناختى هيجان تشـكيل شد. جلسات

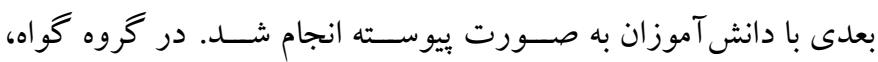

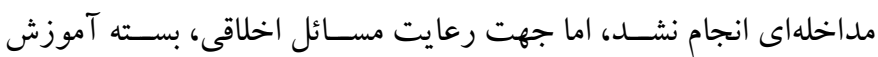

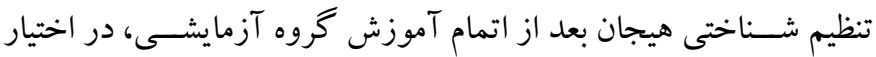
كروه مقايسه نيز قرار داده شد.

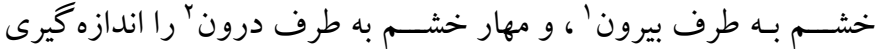

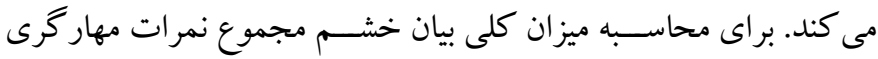

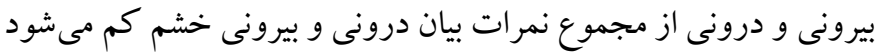

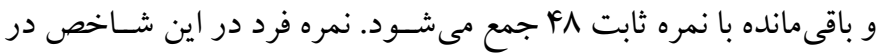

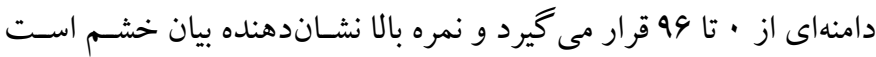

روايى و يايايى اين ابزار در مطالعات مختلف تأييد شـده است. نتايج

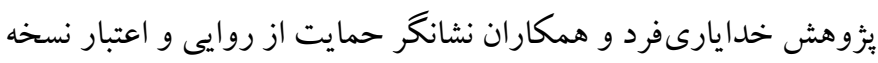

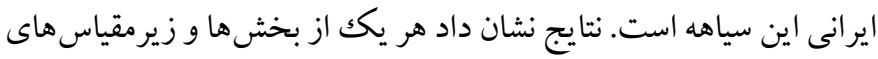
اين سياهه، داراى همسانى درونى ( •/9/ تا سو/•)، ضريب تنصيف (DV/.

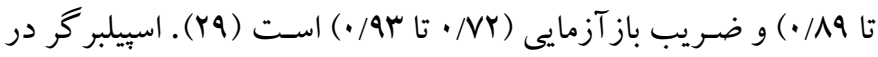
سال هاى 1999 و 1999 ضريب اعتبار براى مقياس هاى بيان خشم و مهار

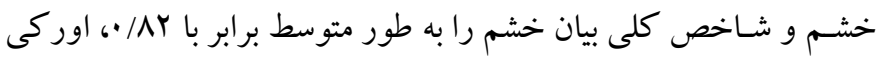

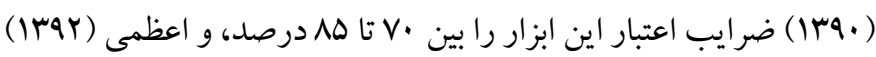
همسـان درونى اين مقياس را با استفاده از ضـريب آلفاى كرونباخ MM/ • كزارش كردهاند (به نقل از 19). در اين يثزوهش از قسمت دوم اين سياهد

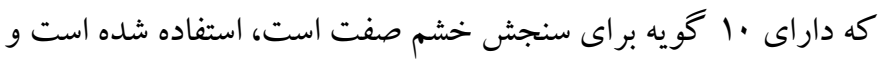

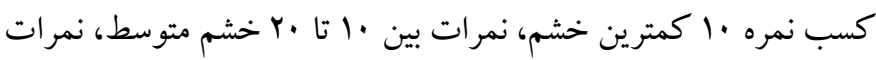

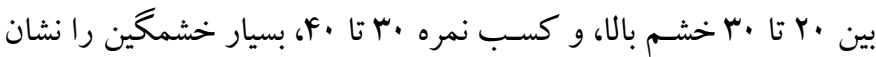
ج) برنـامـهـ مداخلهاى: براى مداخله از يروتكل آموزش تنظيم هيجان مبتى بر مدل فرايند كراس كه يكك شيوه بيشنهادى براى آموزش تنظيم

جدول 1: جلسات آموزش تنظيم شناختى هيجانى كراس

\begin{tabular}{|c|c|c|c|}
\hline تكليف & آموزش & هدف & جلسه \\
\hline 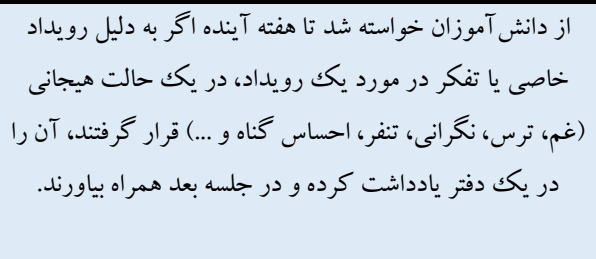 & 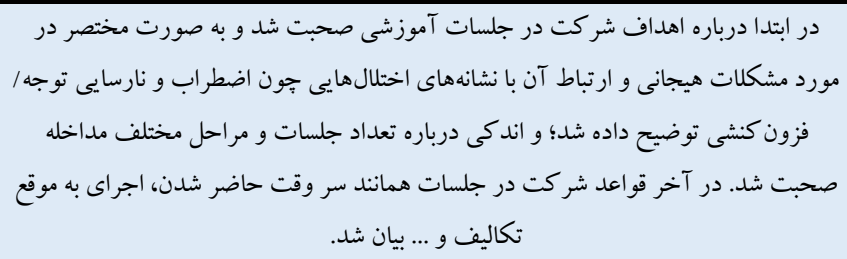 & قواعد شر كت در & يكم \\
\hline 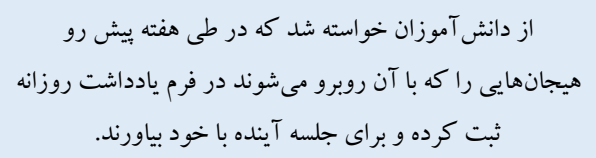 & 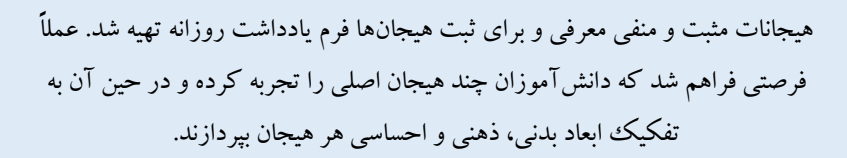 & آشنايى با انتخاب & دوم \\
\hline
\end{tabular}


از دانش آموزان خواسته شد كه در طى هفته آينده، در هنكام

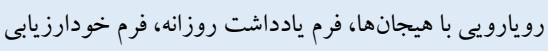

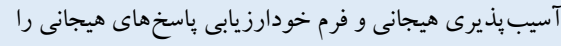
تكميل كنند و در جلسه بعد همر اه خود بياورند.

از دانش آموزان خواسته شد در طى هفته آينده، همانند هفته هاى

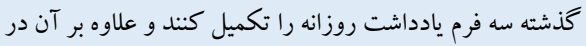

فرم جديدى به نام فرم ثبت فعاليتهاى لذت بختش، بر بر طبق

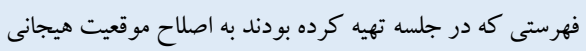
آزاردهنده بيردازند.

از دانش آموزان خواسته شد كه هنگام رويارويى با هيجانهاى

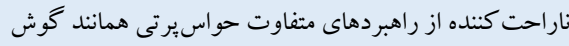

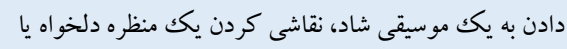

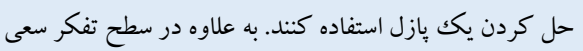

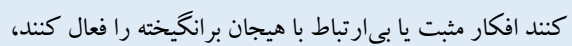

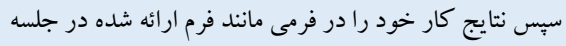
بعد همراه بياورند.

از دانش آموزان خو استه شد كه در طى هفته آينده هنكام

رويارويى با هيجانهاى منفى از دو شيوه استفاده كنند:

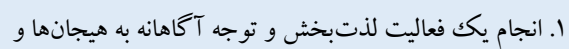

احساسات خوشايند بر آمده از آنها.

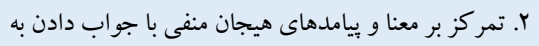

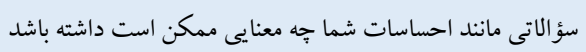

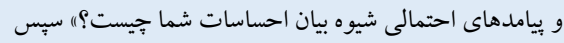

نتايج كار خود را در فرمى مانند جلسه ييش ارائه دهند.

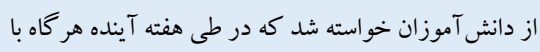

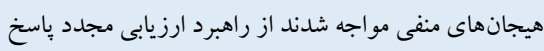
هيجانى به شكل زير استفاده كنند:

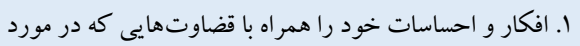
آنها داريد يادداشت كنيد.

r. بر رسى كنيد جرا اين گونه احساس مى كنيد و اين احساس براى شما جه معنايى دارد.

از دانش آموزان خواسته شد در طى هفته آينده هنگام رويارويى دانى

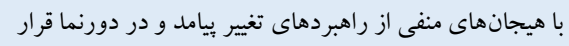

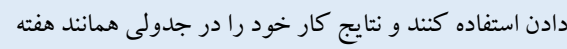
كذشته همراه بياورند.

از دانش آموزان خواسته شد در طى هفته آينده هر گاه با همراه ياوند.

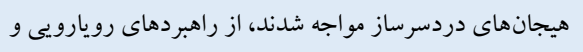

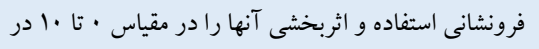
جدولى مانند هفته هاى كذشته مقايسه كنند.

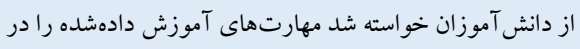
ابتداى جلسه را در هنگام دركير شدن در تجربههاى هيجانى به مانه كار برند و اثربخشى هر يك را ار ارزيابى كنند.
تكميل فرم خودارزيابى باسخهاى هيجانى، به اين صورت كه فضاى جلسه به گونهاى مهيا

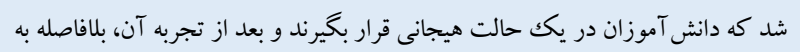

$$
\text { تكميل فرم مخصوص بيردازند. }
$$

با توجه به فرم خودارزيابى آسيبذيذيرى هيجانى، موقعيتهايى كه نياز به اصلاح داشتند

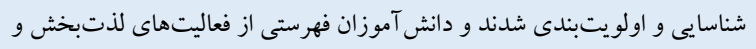

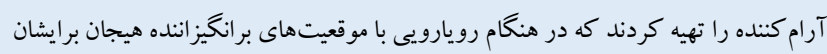

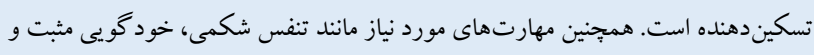
آرامش عضلانى نيز آموزش داده شد.

تكاليف جلسه قبل مرور شدند و مشكلات دانش آموزان در به كار بردن مهارتهاى جديد رفع شد.

اندكى درباره راهبردهاى حواس يرتى و نقش آنها در تنظيم هيجان توضيح داده شد.

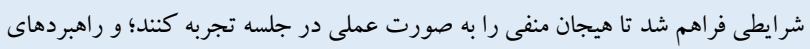

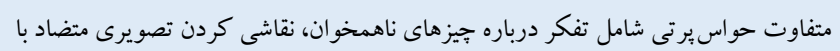
هيجان تجربه شده يا گوش دادن به يك قطعه آموزشى براى تنظيم هيجان استفاده كنيند.

تكاليف جلسه كذشته بررسى و موانع دانش آموزان در به كار بردن آنها رفع شد. اندكى

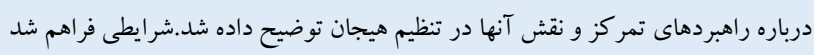

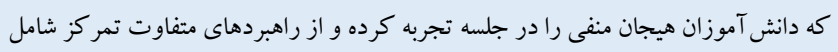

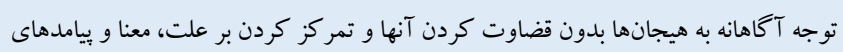

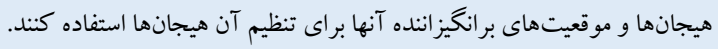

درباره نقش ارزيابىهاى شناختى در افزايش و كاهش بِاسخهاى هيجانى (نمودار مراحل

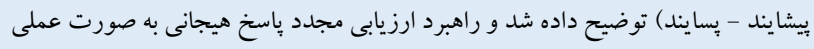

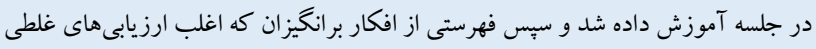

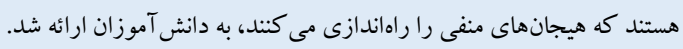

درباره نقش ارزيابىهاى شناختى در افزايش و كاهش ياسخهاى هيجانى توضيح داده شد و

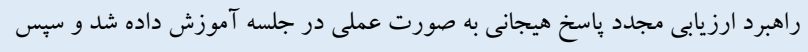

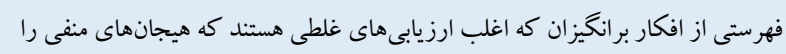
راهاندازى مى كنند، به دانش آموزان ارائه شد.

مواجهه و رويارويى با حالتهاى هيجانى در جلسه به صورت عملى آموزش داده شد.

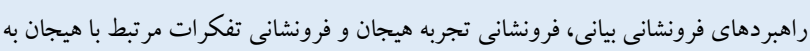

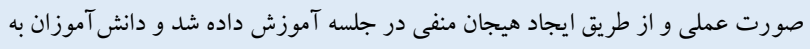

$$
\text { مقايسه اير ادو عدم ابراز هيجان بردان داختند. }
$$

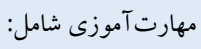

الف) آموزش و تمرين ابراز و تخليه هيجان.

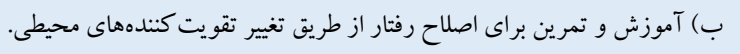

ارزيابى ميزان

آسيبذيذيرى

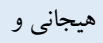
سوم

مهارتهاى هيجانى دانش آموزان

ايجاد تغيير در

موقعيتهاى

جهارم برانگيز اننده هيجان

آموزش مهارتهاى تغيير توجه ينجم

آموزش مهارتهاى مربوط به تمركز ششم تغيير ارزيابىهاى شناختى

تغيير ارزيابىهاى شناختى هشتم تغيير ييامدهاى رفتارى و فيزيولوزى هيجان تغيير ييامدهاى رفتارى و دهم فيزيولوزيكى هيجان 
از دانش آموزان خواسته شد در طى هفته آينده هنكام رويارويى

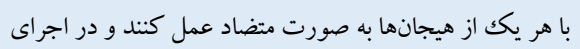
اين تكليف از طبقهبندى ايجاد شده در جلسات استفاده كنند.
مو قعيت هاى بر انغيزانده هر هيجان و راهبر دهاى مؤثر در مورد آن هيجان طبقهبندى شود.

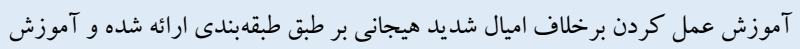

مهارت حل مسئله.
ارزيابى مجدد و

برنامهريزى براى

كاربرد آموزش هامس برئ

جمع بندى جلسات
يازدهم

دوازدهم

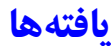

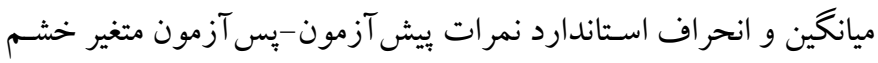

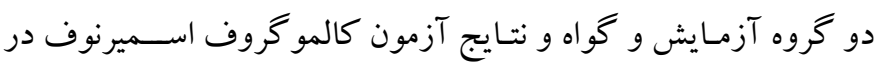

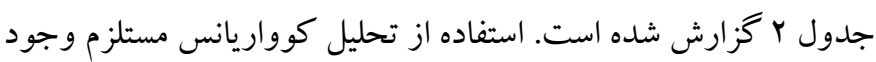

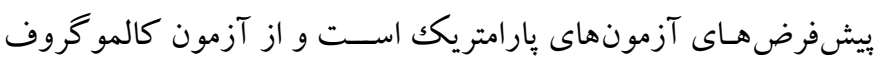

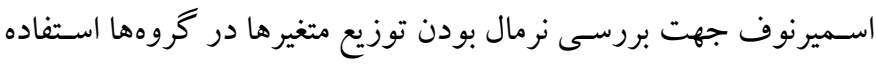

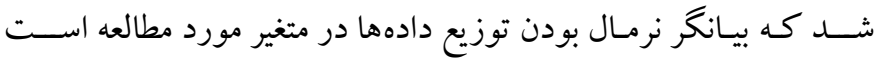

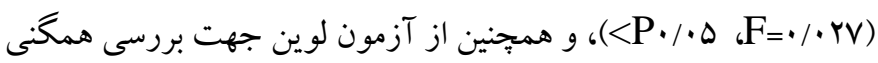

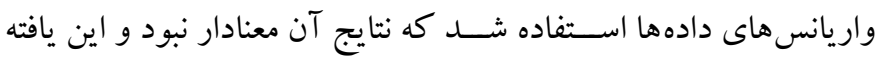

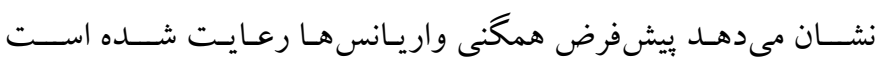

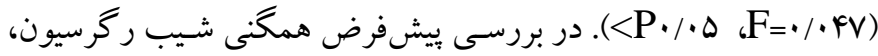
نتايج نشـان داد كه تعامل بيش آزمون با متغير گروه در مرحله بس بس آزمون

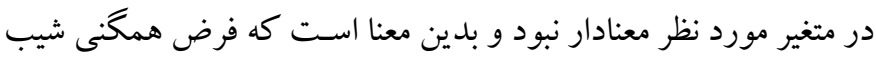

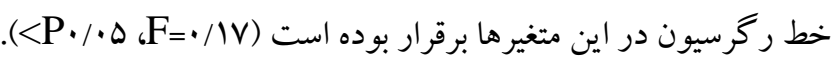

روش اجرا: بِ از دريافت معرفىنامه از دانشـــاه آزاد اســلامى واحد اهواز به اداره آموزش و يرورش تهران، مجوز تهاى للازم از از اين سـازمان

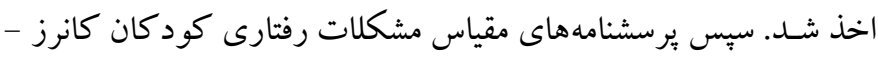

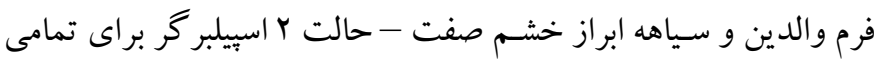

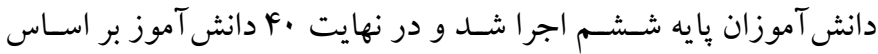

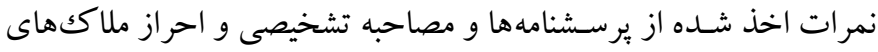

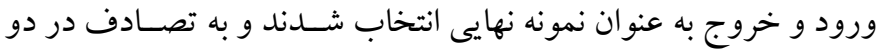

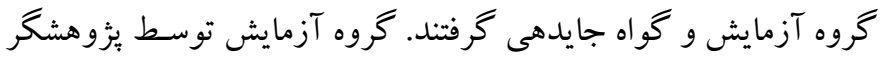

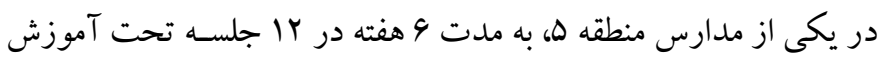

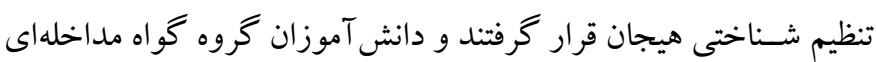

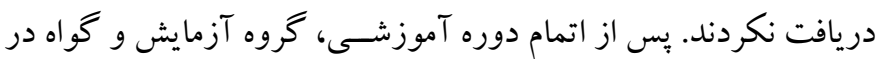

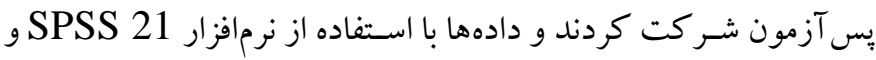
آزمون تحليل كوواريانس تحليل شدند. جهت رعايت ملاحظات اخلاقى،

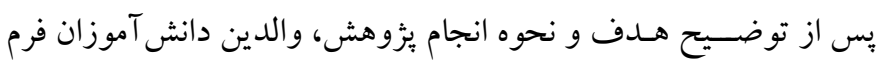

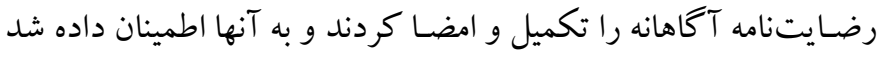
كه اطلاعات شخصى شان محرمانه باقى خو اهد ماند.

جدول rا: شاخصهاى توصيفى نمره خشم كروه آزمايش و كواه

\begin{tabular}{|c|c|c|c|c|c|c|}
\hline $\mathbf{P}$ & كالمو كروف اسميرنوف & انحر اف استاندارد & ميانكين & كروه & وضعيت & متغير \\
\hline$\cdot / \wedge$ &.$/ 4 \pi$ & $9 / 49$ & $r F / Y$ & آزمايش & \multirow{2}{*}{ يِ } & \multirow{4}{*}{ خشم } \\
\hline ا &.$/ 91$ & $19 / \mathrm{VA}$ & $r F / F$ & كواه & & \\
\hline$\cdot / r \cdot \cdot$ & $\cdot / \mathrm{AV}$ & $9 / 1$ & 11 & آزمايش & \multirow{2}{*}{ يس آزمون } & \\
\hline 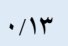 & .194 & $1 / 49$ & $r \Delta / r$ & كواه & & \\
\hline
\end{tabular}

به منظور بررسى تأثير آموزش تنظيم شناختى بر متغير خشم از تحليل كوواريانس تككمتغيرى يككراهه استفاده شد كه در جدول ب خزارش شده است.

جدول بّ: نتايج آزمون تحليل كوواريانس تككمتغرى يكراهد

\begin{tabular}{|c|c|c|c|c|c|c|}
\hline اندازه اثر & $\mathrm{P}$ & Fاره F & ميانخين مجذورات & درجه آزادى & مجموع مجذورات & منبع \\
\hline.$/ 1$ & .1949 & . MFY & 1.191 & 1 & 1.191 & ي يِش آزمون \\
\hline \multirow[t]{2}{*}{$\cdot / 4 \pi$} &.$/ 19$ & rVI/Ar & rVI/Ar & 1 & rVI/Arq & عضويت گروهى \\
\hline & & & FY/YI & rq & $1019 / 49$ & خطا \\
\hline
\end{tabular}


شـخصـيت مرزى و اختلال نارسـيى توجه/ فزون كنشس، نشـان دادند كه

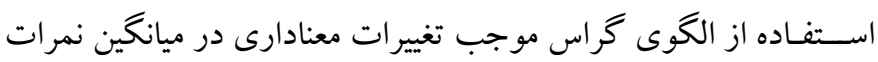

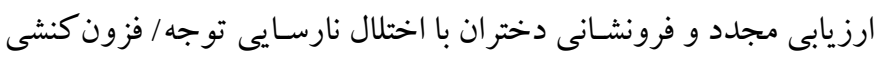

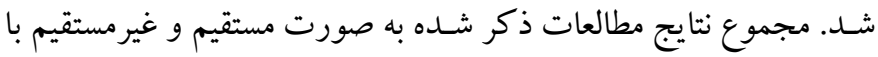
نتايج اين مطالعه همسـو و همخوان اسـت كه مى تو اند در تبيين نتيجه به دست آمده به كار آيد.

يافتهاى بزوهش حاضـر با يافته محمدى و موسـوى (IN) نيز همسو

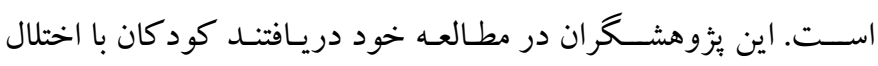
نارسـايى توجه / فزون كنشـى نسـبت به كود كان فاقد اين اختلال داراى سـوح بايين ترى از ارزيابى مجدد شـناختى و بازدارى هيجانى هسـتند.

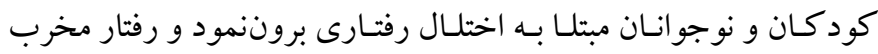

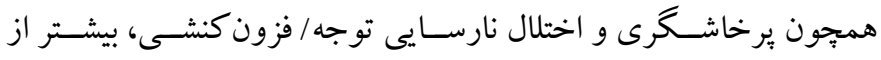

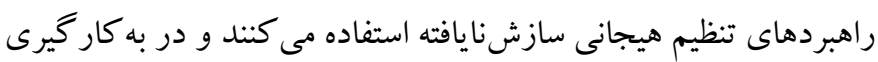
راهبردهاى تنظيم هيجان سـازشيافته دجار نارسايى هستند. همجِين يافته حاضر با نتيجه بزوهش احمدى (IV) نيز همسو است. احمدى در بزوهش

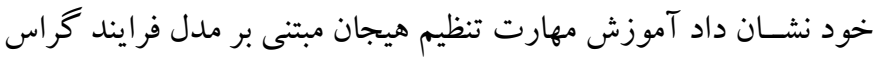

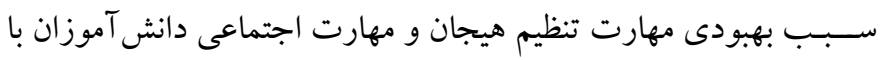

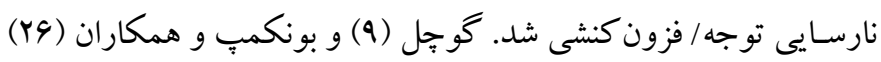
نيز معتقدند كه كود كان با اختلال نارسـايى توجه / فزون كنشى در مهار و بازدارى باسـخ ها داراى مشـكلات اسـاسى هستند و از راهبردهاى تنظيم خشم نامناسب استفاده مى كنند. بنابر اين در تبيين يافتها مى توان اين گونه اعلام كرد كه تحول هيجانى

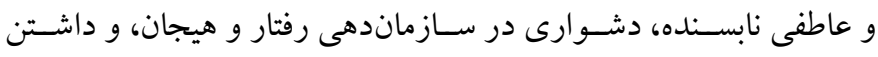
هيجانات منفى، باعث مى شــود كه احسـاسـات و عواطف فرد بر قدرت منطق و اسـتدلالش غلبه داشـته باشــــ و فرد در شــرايط و موقعيتهاى مختلف تنها با در نظر گرفتن جوّ احساسى و عوامل محيطى و بدون توجه

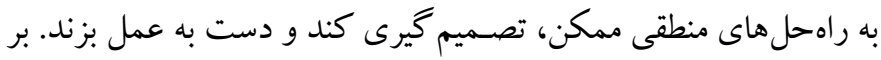

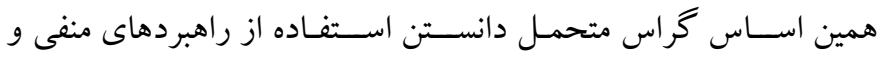
ناكار آمد تنظيم هيجان و عدم تو انايى مناســبـ تنظيم هيجان را از عوامل

مهم و زمينهساز خطر ابتلا به اختلالهاى روانى و رفتارى مىداند (Y I).

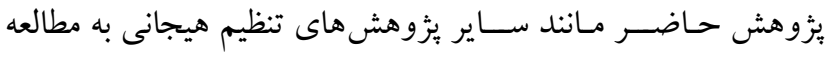
اثربخشى آموزش تنظيم شـناختى هيجان بر خشم دانش آموزان با اختلال
بر اسـاس نتايج جدول با با توجه به ضـريب F محاسـبه شــده، بين

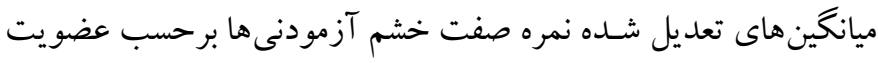

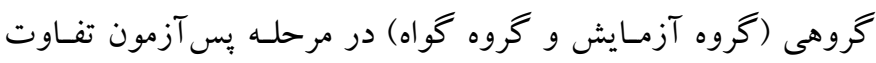

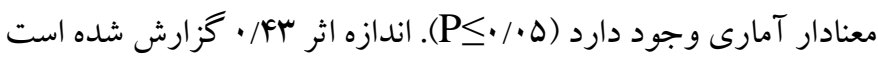
كه مطلوب اسـت، بنابر اين آموزش تنظيم شــناختى هيجان بر نشـانههاى

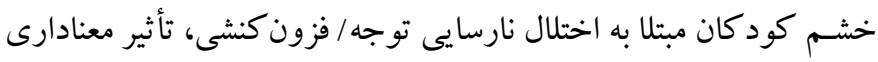
داشته است.

\section{بحث و نتيجه كيرى}

يُروهش حاضـر با هدف بررسى اثربخشى آموزش تنظيم شناختى هيجان

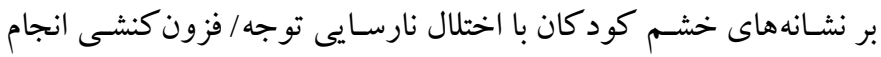

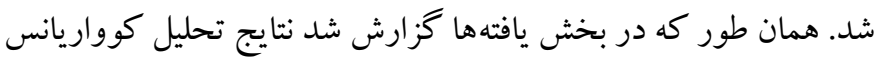

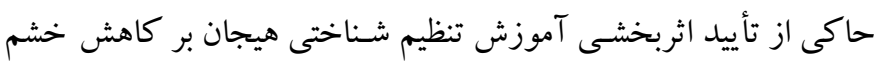

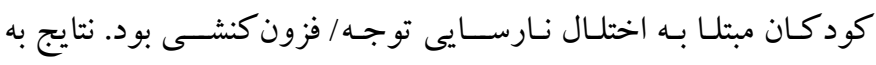

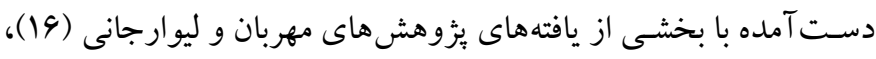

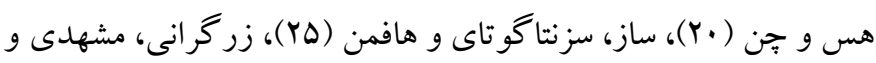

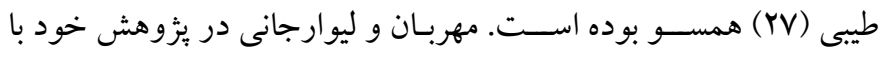
عنوان اثربخشــى آموزش گروهى تنظيم هيجـان مبتنى بر فنون خراس

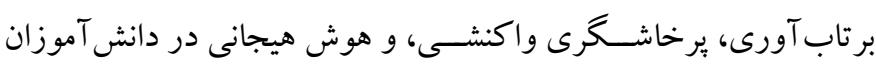

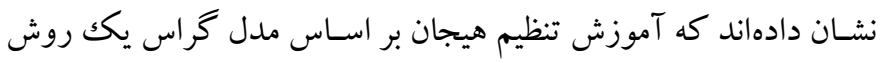

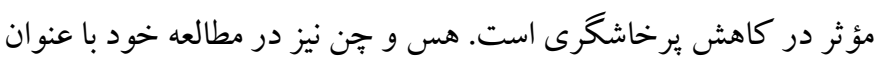

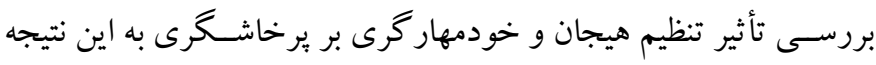

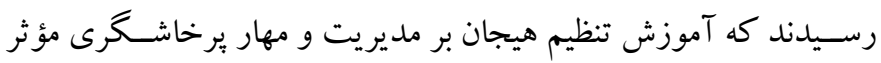

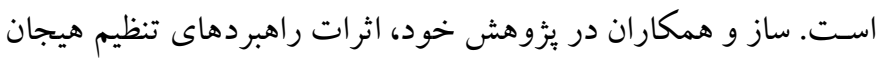

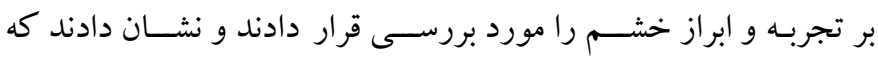

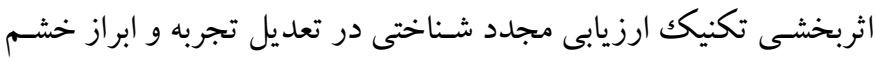

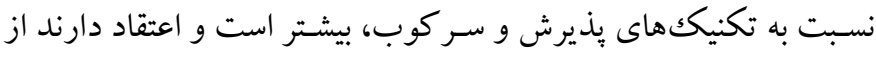

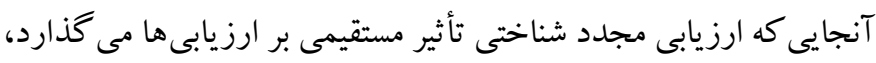

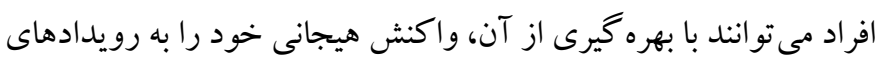

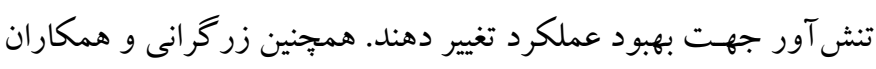

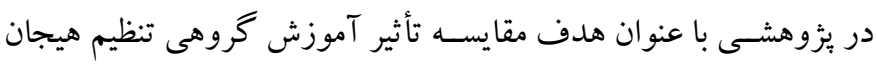

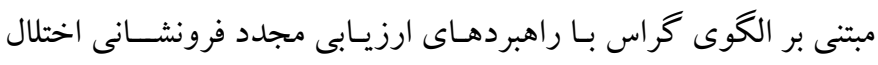


نافرمانى مقابلهاى نيز انجام شـــود. با توجه به اثربخشـى تنظيم شــناختى هيجان بر كاهش نشـانه هاى خشـم در كود كان با اختلال نارسـايى توجه / فزون كنشى در اين مطالعه، در سطح به كار بسته بيشنهاد مىشود تمرينها و فعاليتهاى تنظيم شناختى هيجان به دانش آموزان با اين اختلال آموزش داده شــود و اين برنـامـه در مدارس جهت بهبود فرايندهاى هيجانى اين دانش آموزان (شــامـل بنتج مرحلـه انتخـاب موقعيـت، اصــلاح موقعيت، كسترش توجه، تغيير شناختى، و تعديل پاسخ ) اجرا شود.

\section{ملاحظات اخلاقى}

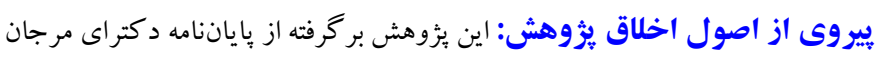

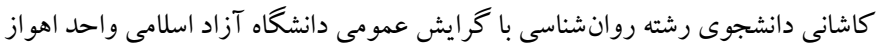

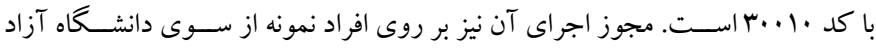

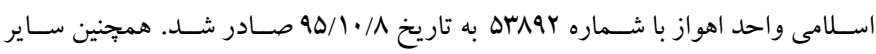

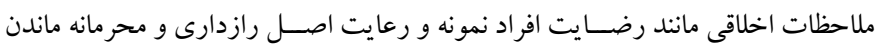
اطلاعات شخصى افراد نمونه در اين مطالعه كاملاً رعايت شده است. حامى مالى: اين مطالعه به طور مستقل و بدون حامى مالى انجام شد.

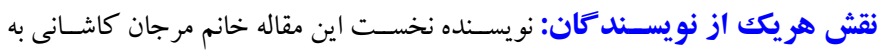
عنو ان مجرى اصسلى اين طرح، نو يسـنده دوم آقاى برويز عســرى به عنوان نو ينســده

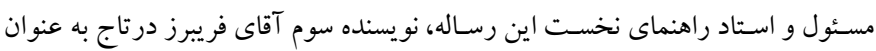

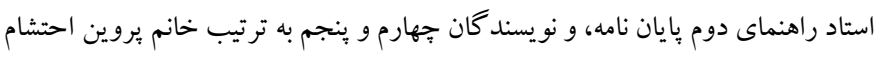
زاده و خانم زهرا افتخار به عنو ان استادان مشاور در اين يروزه نقش داشتند. تضاد منافع: نتايج اين يُوهش براى نويسند كان، هيج گُونه تضاد منافع نداشته است. تشـكر و قدردانى: بدين ترتيب از اسـتادان راهنما و مشـاور اين رسـاله و تمامى افراد

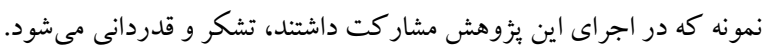

نارسـايى توجه / فزون كنشسى يرداخت. اين بررسـى نيز اثر معنادار خاص اين روش درمـانى را تـأييد كرده اســت و يافته اين بثروهش كوياى اين واقعيـت اســت كـه آموزش تنظيم هيجان كراس بر نشــانهاى خشـــم دانش آموزان با اختلال نارسـايى توجه/ فزون كنشى تأثير مطلوبى داشته و مو جب كاهش آن در دانش آموزان شـــده اســت. در تبيين احتمالى اين يافته مىتوان كفت از آنجايى كه بين راهبردهاى شناختى تنظيم هيجان و اختلـالـات هيجـانى رابطهـ وجود دارد، يس ميى توان كفـت هيجـانهـا بـا

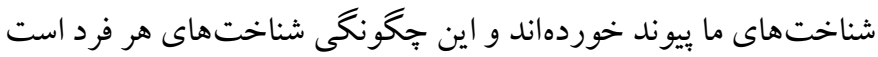
كـه بر ميزان تـأثير محرككهـا و در نتيجـه، شــدت و نوع هيجان وى اثر مى گذارد. بدين ترتيب از آنجايى كه شناخت، احساس، و رفتار كاملاً در تعامل با يكديخر هســتند، تنظيم شــناختى هيجان با مهار توجه و عواقب شناختى هيجان موجب تنظيم هيجان و رفتار مىشود (YF). وجود برخى متغيرهـاى كنترل نشــده در اين مطالعه مانند وضـعيت اقتصـــادى خـانوادههـا، تعـداد فرزنـدان، ترتيـب تولد، موقعيت اجتماعى والدين، و عدم استفاده از روش نمونه گيرى تصادفى، از محدوديتهاى اين يزوهش بود؛ بنابر اين بيشــنهاد مى شـود تا براى افزايش تعميميذيرى نتـايج، اين بثزوهش در ســـاير جوامع داراى فرهنـكَهـاى متفــاوت و خانو ادههاى با وضـعيت اقتصــادى - اجتماعى مختلف، با كنترل عوامل مز احم تأثير گذار، و در صــورت امكان با اســتفاده از روش نمونه گيرى تصـادفى، اجر ا شـود. همجنين در سطح يزوهشى بيشنهاد مىشود كه طى يزووهشهـاى آتى، كـارايى تنظيم شـــــاختى هيجـان در كود كان داراى

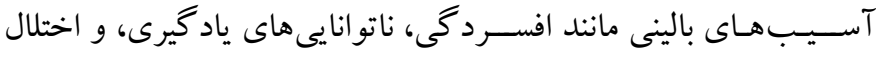




\section{References}

1. American Psychiatric Association. Diagnostic and statistical manual of mental disorders (5th Ed.). Arlington: Author; 2013. . [Persian] [Link]

2. Janatian s, Nori A, Shafti A, Molavi M, Samavatyan $\mathrm{H}$. Effectiveness of play therapy on the bases of cognitive behavior approach on severity of symptoms of Attention Deficit/Hyperactivity Disorder (ADHD) among primary school male students aged 9-11.2008; Journa of Research in Behavioral Science; 6 (2):109118. . [Persian] [Link]

3. Barabadi A, Heydarinasab L. Preliminary validation of the questionnaire State-Trait Anger Experssion Inventory -2 Child and Adolescent (STAXI-2 C/A) amongst a sample of Iranian students aged.12-17 years. Quarterly Journal of Sabzevar University of Medical Sciences. 2013; 20 (3):281-291. [Persian] [Link]

4. Sedaghat S, Moradi O, Ahmadian H. The effectiveness of anger cognitive behavioral group training on aggression of third grade aggressive female students in Baneh's high schools. 2015: Meical Sciences; 24(4)215-220. [Persian][Link]

5. Lochman J.E, Powell N, Clanton N, McElyoy H. Anger and Aggression. In G. Bear and K.Minke (Eds.), Childerens Needs III: Development, Prevention, and Intervention.2006b; (PP. 115-133). Washington, DC: National Association of School Psychologists. [Link]

6. Kokko k, Tremblay R E, Lacourse E, Nagin DS, Vitaro F. Trajectories of Prosocial Behavior and Physical Aggression in Middle Childhood: Links to Adolescent School Dropout and Physical Violence. First Published, 2006. Request For Reprints Should Be Sent To Katia Kokko, Department Of Psychology, Po Box 35, 40014. [Link]

7. Naseh A, The Effect of Mindfulness-Based Group Intervention on Self-esteem and Social Problems in Students with Symptoms of Attention Deficit / Hyperactivity Disorder. 2019: Journal of Child Mental Health; 6 (3)256-268. [Persian] [Link]

8. Fazeli Z, Shirazi E, Asgharnejad Farid A, Afkham Ebrahimi A. Effectiveness of Medication and Combined Medication And Parent Management Training on Visuo-constructive, Attentional, Behavioral and Emotional Indicators of Children with Attention Deficit/Hyperactivity Disorder. 2014: Iranian Journal of Psychiatry and Clinical Psychology;19(4) 264 - 274. [Persian]. [Link]
9. Köchel A, Leutgeb V , Schienle A. Disrupted Response Inhibition Toward Facial Anger Cues in Children With Attention-Deficit Hyperactivity Disorder (ADHD) An Event-Related Potential Study. Journal of Child Neurology. 2013; 29 (4): 459-468. [Link]

10.Motahari Nasab Z, Mirhoseini F, Asli Azad M. Effectiveness of Cognitive Emotional Regulation Training on Emotional Knowledge and Emotional Control of Poorly Supervised Students. Journal of Child Mental Health. 2020; 6 (4): 97-107. [Persian] [Link]

11.Macklem G, Practitioners Guide To Emotion In School-aged Children. Translated By: Kiani A R, Bahrami F. 2007 Arjmandpress. [Link]

12. Gross JJ, Thompson RA. Emotion regulation: conceptual foundations. In: Gross JJ, editor. Handbook of emotion regulation. New York, NY, US: The Guilford Press; 2007: 3-24. [Link]

13. Sharifi Shayan F, Entesar Foumani GH, Hejazi M. The Effectiveness of Collaborative Learning Method on Academic Motivation and Emotion Control in Children with Attention Deficit / Hyperactivity Disorder.2019; Journal of Child Mental Health.6(4):74-84 [Persian] [Link]

14.Li $\mathrm{D}, \mathrm{Li} \mathrm{D}, \mathrm{Wu} \mathrm{N}$, Wang $\mathrm{Z}$. Intergenerational transmission of emotion regulation through parents' reactions to children's negative emotions: Tests of unique, actor, partner, and mediating effects Author links open overlay panel.2019; Children and Youth Services Review.101:113-122. [Link]

15.Kraaij V, Garnefski N. The behavioral emotion regulation questionnaire: development, psychometric properties and relationships with emotional problems and the cognitive emotion regulation questionnaire.Pers Individ Dif. 2019; 137: 56-61. [Link]

16.Mehraban.R, Livarjani.S.H. Evaluation of the effectiveness of emotion regulation group training based on grass techniques on resilience, reactive aggression and emotional intelligence in first year high school students affiliated to Tabriz Quran Kindergarten.2018; Jornal of Woman and Study of Family.10 (39):83-119. [Persian]. [Link]

17. Ahmadi. F.Investigating the effect of emotion regulation training based on Gross process model Students' emotion regulation skills and social skills on the verge ADHD diagnosis.2015; Iran Institute of Information Science and Technology. [Persian]. [Link] 
18. Mohammadi.H, Mosavi.V. Comparison of Emotional Regulation and Self-Control in Children with and without Attention Deficit/Hyperactivity Disorder. 2015; Quarterly Journal of Child Psychological Development. 2(2) 21-33. [Persian]. [Link]

19.Aazami. Y, Sohrabi.F, Borjali.A, Chopan.H. The Effectiveness of Teaching Emotion Regulation Based on Gross Model on Reducing Anger in DrugDependent People.2013; Counseling Culture and Psychoterapy.4 (16):53-68. [Persian]. [Link]

20.Hsieh I.J, Chen Y.Y. Determinants of Aggressive Behavior: Interactive Effects of Emotional Regulation and Inhibitory Control. 2017; Institute of Cognitive Neuroscience, National Central University, Taoyuan City, and Taiwan.12 (4):1/9-9/9. [Link]

21.Miles S.R, Thompson K.E. Stanley M.A., Kent T.A. Single-session emotion regulation skills training to reduce aggression in combat veterans: A clinical innovation case study.2016; Psycholgical Services. 13(2):7-17. [Link]

22. Borjali A, Aazami Y, Chopan H, Arab Quhistani. Effectiveness of emotion regulation strategies for aggression control based on gross model in substance abusers.2015; Iranian Journal of Rehabilitation Research in Nursing.2 (1):53-65. [Persian] [Link]

23. Aazami, Y, Sohrabi, F , Borjali, A, Chopan, H.The Effectiveness of Teaching Emotion Regulation Based on Gross Model in Reducing Impulsivity in DrugDependent People.2014; Quarterly Journal of Research on Addiction. 9(30): 111-128.[Persian] [Link]
24.Movahedi. M, Khaleghipour.SH, Vahabi Homabadi.J. The Effectiveness of Process Management Strategies Of Excitement On The Cognitive Emotion Regulation Of Adolescent Girls With Oppositional Defiant Disorder Authors.2018;Journal Woman and Culture.9(34):111-128.[Persian] [Link]

25.Szasz, P. L., Szentagotai, A., \& Hofmann, S.The effect of emotion regulation strategies on anger. 2011; Behaviour research and therapy.49 (2): 114-119. [Link]

26. Bonekamp E, von Salisch M. Anger regulation in boys with attention deficit hyperactivity disorder (ADHD). 2007; Z Kinder Jugendpsychiatr Psychother. 35(3): 189-197. [Link]

27.Zargarani N, Mashhadi A, Tabibi Z. Comparing the effectiveness of emotion regulation group training based on process model of gross on use of reappraisal and suppression strategies among adolescent girls with symptom of BPD and ADHD. 2016; Pejouhandeh.21 (1):21-29. [Persian] [Link]

28. Shahaeian. A, Shahim. S, Bashash. L, Yousefi.F. Normalization and factor analysis and reliability of the short form for parents of Conners grading scale for 6 to 11 year old children in Shiraz.2007; Journal of Psychological Studies, Al-Zahra University, 3 (3), pp. 97-120. [Persian] [Link]

29.Khodayarifard. M, Gholamali Lavasani.M, Akbari Zardkhaneh.S, Liaghat.S. Psychometric Properties of Spielberger's State-Trait Anger Expression Inventory-2 among of Iranian students.2010; Archives of Rehabilitation.11 (1):47-56. [Persian] [Link] 